Dokuz Eylül Üniversitesi-Mühendislik Fakültesi

Fen ve Mühendislik Dergisi

Cilt 19 Sayı 55 Ocak 2017
Dokuz Eylul University-Faculty of Engineering Journal of Science and Engineering Volume 19 Issue 55 January 2017

DOI: 10.21205/deufmd. 2017195511

\title{
Effectiveness of Steam Curing on Repairing Early Age Mortar Damages
}

\section{Hüseyin YİĞİTER*1}

${ }^{1}$ Dokuz Eylül University, Engineering Faculty, Civil Engineering Department, İzmir.

(Alınıs / Received: 16.08.2016, Kabul / Accepted: 28.11.2016, Online Yayınlanma/ Published Online: 09.01.2017)

Keywords Portland Cement Mortar, Steam Curing, Healing, Early Age Mechanical Properties.

\begin{abstract}
Standard, steam and air curing methods were investigated in the scope of presented study to assess the healing performance of early age mortar damages. Compressive stress levels of $50,75,90$ and $100 \%$ of strength were adapted to Portland cement mortar or blended cement mortar specimens at early ages. Test results exhibited that preloading level under $90 \%$ of instantaneous strength until 4 days, did not affect the ultimate strength for standard cured specimens. On the contrary, results obtained from air cured specimens preloaded after 2 days were almost equal or greater than that of control specimens. Surprisingly, steam curing application could not provide expected recuperation; however, less variable strength results were obtained. Blended cement mortar specimens achieved better results with steam curing process. Besides, it was possible to reach $53 \mathrm{MPa}$ compressive strength by selecting a proper curing treatment even in the case of full damage.
\end{abstract}

\section{Erken Dönem Harç Hasarlarının Tamirinde Buhar Kürünün Etkinliğinin Araştırılması}

\begin{abstract}
Anahtar Kelimeler Özet: $\mathrm{Bu}$ çalışma kapsamında erken dönemde oluşan çimento Portland Çimentosu Harcı, Buhar Kürü, İyileşme, Erken Dönem Mekanik Özellikler. harcı hasarlarının iyileştirilmesinde standart kür, buhar kürü ve hava kürü yöntemlerinin etkinliği araştırılmıştır. Portland çimentosu ve katkılı çimento harçlarına 1., 2., 4. ve 7. günlerde basınç dayanımlarının \%50, 75, 90 ve 100 seviyelerinde gerilme uygulanmıştır. Test sonuçları 4. güne kadar \%90'dan daha düşük ön yükleme uygulamasının standart kürlü numunelerin nihai dayanımlarını etkilemediğini göstermiştir. Diğer yandan 2 günden sonra ön yükleme yapılmış ve havada kür edilmiş numunelerin test sonuçları kontrol numunelerine eşit veya daha büyüktür. Buhar kürü uygulaması beklenen mukavemet artışını sağlamamış ancak daha az değişken dayanım sonuçları elde edilmiştir. Katkılı çimento ile üretilmiș harç numunelerinde buhar kürü uygulaması ile daha iyi sonuçlar elde edilmiştir. Uygun kür yönteminin seçimi ile tam hasar durumunda bile $53 \mathrm{MPa}$ basınç dayanımı sonucuna ulaşmak mümkün görünmektedir.
\end{abstract}




\section{Introduction}

Cracks existing in reinforced concrete structures affect the structure in two manners. On one hand, reduced strength put the mechanical safety at a great risk; on the other hand increased permeability shortens the service life of the structure. In most cases, both mechanisms synergistically affect each other. Therefore, healing of the cracks either in micro or macro scale has a great importance in terms of structural safety, durable service life and economical costs.

However, early age concrete damage would be a very difficult issue to solve the problem without any lost in economy or a period of time. Deflection of molds or early demolding of formworks, various shrinkage mechanisms, thermal gradients, hydration process and etc. were main causes of early age concrete cracks. In many cases there would be no chance to repair the major damages of reinforced concrete elements. Minor cracks could be eliminated by healing or injection techniques.

Recent years great efforts being made on developing efficient methods to repair the concrete cracks or damages. Many researchers have concluded that small cracks in concrete can heal by autogenous healing phenomenon [1-7]. Alyousif et al. noted that up to $92 \%$ of healing was determined depending on the type of the mixture and curing history [8]. In general, the self-healing mechanism of an unspecific concrete is related to the chemical reactions of unhydrated particles of cement and carbonation process $[2,3,9]$. Healing capacity for this phenomenon is restricted with age of concrete and the crack width $[10,11]$.

Repairing the damage with agents added the composite at initial mixing stage were being deeply considered. Bacteria induced mineral precipitation to improve the healing capacity was under investigation with disadvantages such as, the bacteria would die over time even encapsulated or guard protected due to the harsh environment inside the concrete. In addition, moist environment was not guaranteed that have a great influence on the crack repair effect [12]. The addition of healing agents such as bacteria and/or chemical compounds to the paste may result in unwanted decrease of strength properties [13].

Chemical expansive additives show the better crack healing performance by filling the cracks and enhancing the mechanical properties [14]. However, an additional self-cracking risk could be occurred by restrained deformation unless the dosage was well proportioned [15].

Being in such a tight situation, extending the curing time or enhancing the efficiency of curing method could be an alternative way. Steam curing of cement and concrete is a well-known thermal treatment process that greatly increases the early age strength. However, a loss in ultimate strength values would be expected $[16,17]$. This commonly used technique in precast industry could sometimes be selected to activate the pozzolanic material to form secondary calcium silicate hydrate gel which increases the strength value of the composite [18].

In the present study, curing conditions and particularly steam curing application have been investigated with regard to strength gain capacities of Portland cement mortars. Two types of Portland cements mortars were used in the assessment of damage degree and preloading age variations. Mechanical test results and optical microscope observations were evaluated comparatively. 


\section{Experimental Study}

An experimental program has been carried out according to following details. The experimental variables include cement type (CEM I $42.5 \mathrm{R}$ and CEM-II/B-M(L-W) $42.5 \quad \mathrm{R})$, age of preliminary loading $(1,2,4$ and 7 days) and curing method (standard water curing, atmospheric steam curing and air curing). Compressive strength values of preloaded specimens were investigated at $28^{\text {th }}$ day.

\subsection{Materials}

An ordinary type Portland cement CEM I 42.5 $\mathrm{R}$ and a blended cement CEM-II/B$\mathrm{M}(\mathrm{L}-\mathrm{W}) 42.5 \mathrm{R}$ were used in this study. The chemical composition and physical properties of cementitious materials are given in Table 1.

Table 1. Chemical composition and physical properties of cementitious materials.

\begin{tabular}{|c|c|c|}
\hline $\begin{array}{l}\text { Composition / } \\
\text { Property }\end{array}$ & $\begin{array}{l}\text { CEM-I } \\
42.5 R\end{array}$ & $\begin{array}{r}\text { CEM-II/B- } \\
\mathrm{M}(\mathrm{L}-\mathrm{W}) \\
42.5 \mathrm{R}\end{array}$ \\
\hline $\mathrm{CaO}(\%)$ & 63.27 & 53.48 \\
\hline $\mathrm{SiO}_{2}(\%)$ & 19.04 & 23.58 \\
\hline $\mathrm{Al}_{2} \mathrm{O}_{3}(\%)$ & 5.65 & 8.77 \\
\hline $\mathrm{Fe}_{2} \mathrm{O}_{3}(\%)$ & 2.21 & 2.64 \\
\hline MgO (\%) & 1.27 & 1.37 \\
\hline $\mathrm{SO}_{3}(\%)$ & 3.50 & 3.46 \\
\hline $\mathrm{Na}_{2} \mathrm{O}(\%)$ & 0.19 & 0.19 \\
\hline $\mathrm{K}_{2} \mathrm{O}(\%)$ & 0.93 & 0.99 \\
\hline F. CaO (\%) & 1.00 & 1.72 \\
\hline I.R. (\%) & 0.73 & 11.11 \\
\hline L.O.I. (\%) & 3.40 & 5.18 \\
\hline $\begin{array}{l}\text { Specific gravity } \\
\left(\mathrm{gr} / \mathrm{cm}^{3}\right)\end{array}$ & 3.11 & 3.00 \\
\hline $\begin{array}{l}\text { Blaine } \\
\left(\mathrm{cm}^{2} / \mathrm{gr}\right)\end{array}$ & 3820 & 4443 \\
\hline$>32 \mu \mathrm{m}(\%)$ & 28.37 & 11.98 \\
\hline$>45 \mu \mathrm{m}(\%)$ & 15.28 & 4.37 \\
\hline$>90 \mu \mathrm{m}(\%)$ & 2.56 & 0.25 \\
\hline Initial set (min.) & 158 & 173 \\
\hline Final set (min.) & 200 & 223 \\
\hline Expansion (mm) & 1.00 & 1.60 \\
\hline
\end{tabular}

Crushed limestone sand was used as aggregate with the specific gravity of 2.65. Maximum aggregate size was $4 \mathrm{~mm}$ and the gradation curve of limestone was very close to standard silica sand.

Same mixture proportions were used in mortar preparation works for two types of cement. Water/cement ratio and aggregate/cement ratio were 0.5 and 3.0 , respectively.

Test results and the abbreviations in specimen codes which denote cement type, age of preliminary loading, stress percentage at preliminary loading and curing method after loading, respectively, have been given in Table 2 and 3.

\subsection{Procedure}

The mixtures were prepared in a standard vertical axis Hobart mixer. Dry materials were mixed with the agitating speed of $60 \mathrm{rpm}$ for about 1 minute. After water addition, mixtures were mixed for about 1 minute with the agitating speed of $60 \mathrm{rpm}$ and then $120 \mathrm{rpm}$, respectively. The consistencies of mixtures were in the range of 115-120 $\mathrm{mm}$ according to mini slump flow test. Casting and compaction of $5 \times 5 \times 5 \mathrm{~cm}$ cubic specimens realized by hand operations and vibration.

The specimen moulds were kept in a humid chamber for $24 \mathrm{~h}$ at room temperature of $20{ }^{\circ} \mathrm{C}$. After demoulding, specimens were exposed to standard water curing up to preliminary loading age.

Early age loading tests have been applied to specimens with a load controlled testing machine. Firstly, compressive strength values have been determined. Tests were terminated at the point of 5 $\%$ load reduction after the peak load. Compressive stress values of 90,75 and 
$50 \%$ of compressive strength have been applied to next group of the specimens. Then, post curing stage has been started. Standard water curing at $20{ }^{\circ} \mathrm{C}$ was performed to one group of specimens until $28^{\text {th }}$ day. Another group of specimens have been subjected to steam curing at $100^{\circ} \mathrm{C}$. Target temperature has been reached within 6 hours and heat treatment duration was selected for 12 hours. Controlled cooling period took 4 hours. Specimens were kept in laboratory atmosphere until $28^{\text {th }}$ day at the temperature range of $15-20{ }^{\circ} \mathrm{C}$ with the relative humidity of 50-60\%. Last group of specimens have been exposed to laboratory atmosphere up to $28^{\text {th }}$ day. Average of three identical test results was used to evaluate the mechanical performance.

\section{Results and Discussion}

Applied early age stresses and compressive strength values of the specimens at $28^{\text {th }}$ day were presented in Table 2 for CEM I specimens and in Table 3 for CEM II specimens.

Compressive strength developments for CEM I and CEM II specimens are shown in Figure 1. 28 $8^{\text {th }}$ day compressive strength of CEM I specimens was measured as $60.1 \mathrm{MPa}$. Relative strengths for 1, 2, 4 and 7 days were 48, 64,73 and $81 \%$ respectively. Strength value for blended cement was $55.8 \mathrm{MPa}$, and relative strengths were 32, 46, 67 and 73 for corresponding ages. As expected Portland cement exhibit greater strength values for early ages. Blended cement CEM II specimens made up the differences in strength values at $28^{\text {th }}$ day.

Compressive strength value variations of standard cured CEM I specimens after various stress application at different loading ages were given in Figure 2 .
It can be said that pre-stressing level has a great importance on ultimate strength. Also it seems that it has a threshold level between 90-100\%. As expected strength gain for fully damaged specimens was kept at low level. Lowering the preloading level under $90 \%$ of instantaneous strength, do not affect the ultimate strength especially for the specimens preloaded at early ages. Compressive strength values of specimens pre-loaded at 1 or 2 day were about $60 \mathrm{MPa}$ level, while $28^{\text {th }}$ day strength of water cured specimens was $60.1 \mathrm{MPa}$ without any preloading. Consequently, no mechanically permanent damage was observed for these specimens.

On the other hand, for preloading level of $50-90 \%$ increase in preloading age beyond 2 days, decreased the ultimate strength values about $5 \mathrm{MPa}(8 \%$ strength loss) for 4 days and 6-10 $\mathrm{MPa}$ (10-16\% strength loss) for 7 days.

Zhong and Yao noted that self-healing of concrete was markedly influence by its damage degree and there exists a damage degree threshold which depends on materials. The authors also concluded that the threshold for normal strength concrete was higher than that for high strength concrete [11].

From the view point of loading age, it can be said that early preloaded specimens were less affected from the damage. Two reasons have effect upon this phenomenon. Firstly, due to early time of hydration compressive strength values were lower, hence applied stress were lower. Most importantly, at the early ages of hydration process, much non-hydrated cementitious particles capable to fill the cracks were still present around the damaged area. 
H. Yiğiter / Effectiveness of Steam Curing on Repairing Early Age Mortar Damages

Table 2. Test results of CEM I specimens

\begin{tabular}{|c|c|c|c|c|c|c|}
\hline $\begin{array}{l}\text { Specimen } \\
\text { code }\end{array}$ & $\begin{array}{l}\text { Cement } \\
\text { type }\end{array}$ & $\begin{array}{l}\text { Preloading } \\
\text { age (day) }\end{array}$ & $\begin{array}{l}\text { Stress } \\
\text { level (\%) }\end{array}$ & $\begin{array}{l}\text { Stress } \\
(\mathrm{MPa})\end{array}$ & $\begin{array}{l}\text { Curing } \\
\text { type }\end{array}$ & $\begin{array}{l}\text { 28th day strength } \\
\text { (MPa) }\end{array}$ \\
\hline I-1-50-STD & I & 1 & 50 & 14.5 & STANDARD & 61.3 \\
\hline I-1-75-STD & I & 1 & 75 & 21.7 & STANDARD & 60.6 \\
\hline I-1-90-STD & I & 1 & 90 & 26.0 & STANDARD & 60.5 \\
\hline I-1-100-STD & I & 1 & 100 & 29.5 & STANDARD & 51.7 \\
\hline I-2-50-STD & I & 2 & 50 & 19.1 & STANDARD & 58.2 \\
\hline I-2-75-STD & I & 2 & 75 & 28.6 & STANDARD & 60.5 \\
\hline I-2-90-STD & I & 2 & 90 & 34.4 & STANDARD & 59.1 \\
\hline I-2-100-STD & I & 2 & 100 & 37.1 & STANDARD & 47.6 \\
\hline I-4-50-STD & I & 4 & 50 & 21.9 & STANDARD & 55.5 \\
\hline I-4-75-STD & I & 4 & 75 & 32.9 & STANDARD & 56.4 \\
\hline I-4-90-STD & I & 4 & 90 & 39.5 & STANDARD & 55.7 \\
\hline I-4-100-STD & I & 4 & 100 & 46.6 & STANDARD & 48.8 \\
\hline I-7-50-STD & I & 7 & 50 & 24.3 & STANDARD & 52.7 \\
\hline I-7-75-STD & I & 7 & 75 & 36.4 & STANDARD & 50.4 \\
\hline I-7-90-STD & I & 7 & 90 & 43.7 & STANDARD & 54.5 \\
\hline I-7-100-STD & I & 7 & 100 & 50.2 & STANDARD & 45.8 \\
\hline I-1-50-STM & I & 1 & 50 & 14.5 & STEAM & 41.9 \\
\hline I-1-75-STM & I & 1 & 75 & 21.7 & STEAM & 41.6 \\
\hline I-1-90-STM & I & 1 & 90 & 26.0 & STEAM & 42.7 \\
\hline I-1-100-STM & I & 1 & 100 & 28.8 & STEAM & 36.7 \\
\hline I-2-50-STM & I & 2 & 50 & 19.1 & STEAM & 45.1 \\
\hline I-2-75-STM & I & 2 & 75 & 28.6 & STEAM & 43.4 \\
\hline I-2-90-STM & I & 2 & 90 & 34.4 & STEAM & 42.2 \\
\hline I-2-100-STM & I & 2 & 100 & 38.9 & STEAM & 37.7 \\
\hline I-4-50-STM & I & 4 & 50 & 21.9 & STEAM & 46.9 \\
\hline I-4-75-STM & I & 4 & 75 & 32.9 & STEAM & 43.4 \\
\hline I-4-90-STM & I & 4 & 90 & 39.5 & STEAM & 43.8 \\
\hline I-4-100-STM & I & 4 & 100 & 42.9 & STEAM & 37.3 \\
\hline I-7-50-STM & I & 7 & 50 & 24.3 & STEAM & 45.3 \\
\hline I-7-75-STM & I & 7 & 75 & 36.4 & STEAM & 42.1 \\
\hline I-7-90-STM & I & 7 & 90 & 43.7 & STEAM & 42.7 \\
\hline I-7-100-STM & I & 7 & 100 & 46.8 & STEAM & 34.7 \\
\hline I-1-50-AIR & I & 1 & 50 & 14.5 & AIR & 50.7 \\
\hline I-1-75-AIR & I & 1 & 75 & 21.7 & AIR & 54.5 \\
\hline I-1-90-AIR & I & 1 & 90 & 26.0 & AIR & 51.9 \\
\hline I-1-100-AIR & I & 1 & 100 & 28.5 & AIR & 45.9 \\
\hline I-2-50-AIR & I & 2 & 50 & 19.1 & AIR & 59.9 \\
\hline I-2-75-AIR & I & 2 & 75 & 28.6 & AIR & 59.7 \\
\hline I-2-90-AIR & I & 2 & 90 & 34.4 & AIR & 59.2 \\
\hline I-2-100-AIR & I & 2 & 100 & 39.5 & AIR & 53.0 \\
\hline I-4-50-AIR & I & 4 & 50 & 21.9 & AIR & 62.4 \\
\hline I-4-75-AIR & I & 4 & 75 & 32.9 & AIR & 60.6 \\
\hline I-4-90-AIR & I & 4 & 90 & 39.5 & AIR & 61.7 \\
\hline I-4-100-AIR & I & 4 & 100 & 42.1 & AIR & 51.2 \\
\hline I-7-50-AIR & I & 7 & 50 & 24.3 & AIR & 59.2 \\
\hline I-7-75-AIR & I & 7 & 75 & 36.4 & AIR & 58.6 \\
\hline I-7-90-AIR & I & 7 & 90 & 43.7 & AIR & 58.2 \\
\hline I-7-100-AIR & I & 7 & 100 & 48.8 & AIR & 50.3 \\
\hline
\end{tabular}


H. Yiğiter / Effectiveness of Steam Curing on Repairing Early Age Mortar Damages

Table 3. Test results of CEM II specimens

\begin{tabular}{|c|c|c|c|c|c|c|}
\hline $\begin{array}{l}\text { Specimen } \\
\text { code }\end{array}$ & $\begin{array}{l}\text { Cement } \\
\text { type }\end{array}$ & $\begin{array}{l}\text { Preloading } \\
\text { age (day) }\end{array}$ & $\begin{array}{l}\text { Stress } \\
\text { level }(\%)\end{array}$ & $\begin{array}{l}\text { Stress } \\
(\mathrm{MPa})\end{array}$ & $\begin{array}{l}\text { Curing } \\
\text { type }\end{array}$ & $\begin{array}{l}\text { 28th day strength } \\
(\mathrm{MPa})\end{array}$ \\
\hline II-1-50-STD & II & 1 & 50 & 8.6 & STANDARD & 52.1 \\
\hline II-1-75-STD & II & 1 & 75 & 13.0 & STANDARD & 50.6 \\
\hline II-1-90-STD & II & 1 & 90 & 15.6 & STANDARD & 54.3 \\
\hline II-1-100-STD & II & 1 & 100 & 17.4 & STANDARD & 46.7 \\
\hline II-2-50-STD & II & 2 & 50 & 13.0 & STANDARD & 51.2 \\
\hline II-2-75-STD & II & 2 & 75 & 19.5 & STANDARD & 49.3 \\
\hline II-2-90-STD & II & 2 & 90 & 23.4 & STANDARD & 49.0 \\
\hline II-2-100-STD & II & 2 & 100 & 27.1 & STANDARD & 46.3 \\
\hline II-4-50-STD & II & 4 & 50 & 18.8 & STANDARD & 54.5 \\
\hline II-4-75-STD & II & 4 & 75 & 28.3 & STANDARD & 55.2 \\
\hline II-4-90-STD & II & 4 & 90 & 33.9 & STANDARD & 57.9 \\
\hline II-4-100-STD & II & 4 & 100 & 38.3 & STANDARD & 46.3 \\
\hline II-7-50-STD & II & 7 & 50 & 20.3 & STANDARD & 52.3 \\
\hline II-7-75-STD & II & 7 & 75 & 30.5 & STANDARD & 52.8 \\
\hline II-7-90-STD & II & 7 & 90 & 36.6 & STANDARD & 53.3 \\
\hline II-7-100-STD & II & 7 & 100 & 40.3 & STANDARD & 45.8 \\
\hline II-1-50-STM & II & 1 & 50 & 8.6 & STEAM & 44.3 \\
\hline II-1-75-STM & II & 1 & 75 & 13.0 & STEAM & 45.1 \\
\hline II-1-90-STM & II & 1 & 90 & 15.6 & STEAM & 47.0 \\
\hline II-1-100-STM & II & 1 & 100 & 18.3 & STEAM & 38.3 \\
\hline II-2-50-STM & II & 2 & 50 & 13.0 & STEAM & 44.2 \\
\hline II-2-75-STM & II & 2 & 75 & 19.5 & STEAM & 44.5 \\
\hline II-2-90-STM & II & 2 & 90 & 23.4 & STEAM & 43.9 \\
\hline II-2-100-STM & II & 2 & 100 & 25.5 & STEAM & 38.6 \\
\hline II-4-50-STM & II & 4 & 50 & 18.8 & STEAM & 48.9 \\
\hline II-4-75-STM & II & 4 & 75 & 28.3 & STEAM & 48.3 \\
\hline II-4-90-STM & II & 4 & 90 & 33.9 & STEAM & 48.5 \\
\hline II-4-100-STM & II & 4 & 100 & 37.8 & STEAM & 39.5 \\
\hline II-7-50-STM & II & 7 & 50 & 20.3 & STEAM & 49.8 \\
\hline II-7-75-STM & II & 7 & 75 & 30.5 & STEAM & 48.7 \\
\hline II-7-90-STM & II & 7 & 90 & 36.6 & STEAM & 48.5 \\
\hline II-7-100-STM & II & 7 & 100 & 41.0 & STEAM & 37.9 \\
\hline II-1-50-AIR & II & 1 & 50 & 8.6 & AIR & 44.4 \\
\hline II-1-75-AIR & II & 1 & 75 & 13.0 & AIR & 47.6 \\
\hline II-1-90-AIR & II & 1 & 90 & 15.6 & AIR & 50.0 \\
\hline II-1-100-AIR & II & 1 & 100 & 18.6 & AIR & 42.4 \\
\hline II-2-50-AIR & II & 2 & 50 & 13.0 & AIR & 49.0 \\
\hline II-2-75-AIR & II & 2 & 75 & 19.5 & AIR & 50.4 \\
\hline II-2-90-AIR & II & 2 & 90 & 23.4 & AIR & 52.8 \\
\hline II-2-100-AIR & II & 2 & 100 & 25.3 & AIR & 45.0 \\
\hline II-4-50-AIR & II & 4 & 50 & 18.8 & AIR & 57.0 \\
\hline II-4-75-AIR & II & 4 & 75 & 28.3 & AIR & 57.8 \\
\hline II-4-90-AIR & II & 4 & 90 & 33.9 & AIR & 59.4 \\
\hline II-4-100-AIR & II & 4 & 100 & 37.0 & AIR & 48.0 \\
\hline II-7-50-AIR & II & 7 & 50 & 20.3 & AIR & 61.7 \\
\hline II-7-75-AIR & II & 7 & 75 & 30.5 & AIR & 59.4 \\
\hline II-7-90-AIR & II & 7 & 90 & 36.6 & AIR & 60.5 \\
\hline II-7-100-AIR & II & 7 & 100 & 40.6 & AIR & 48.5 \\
\hline
\end{tabular}




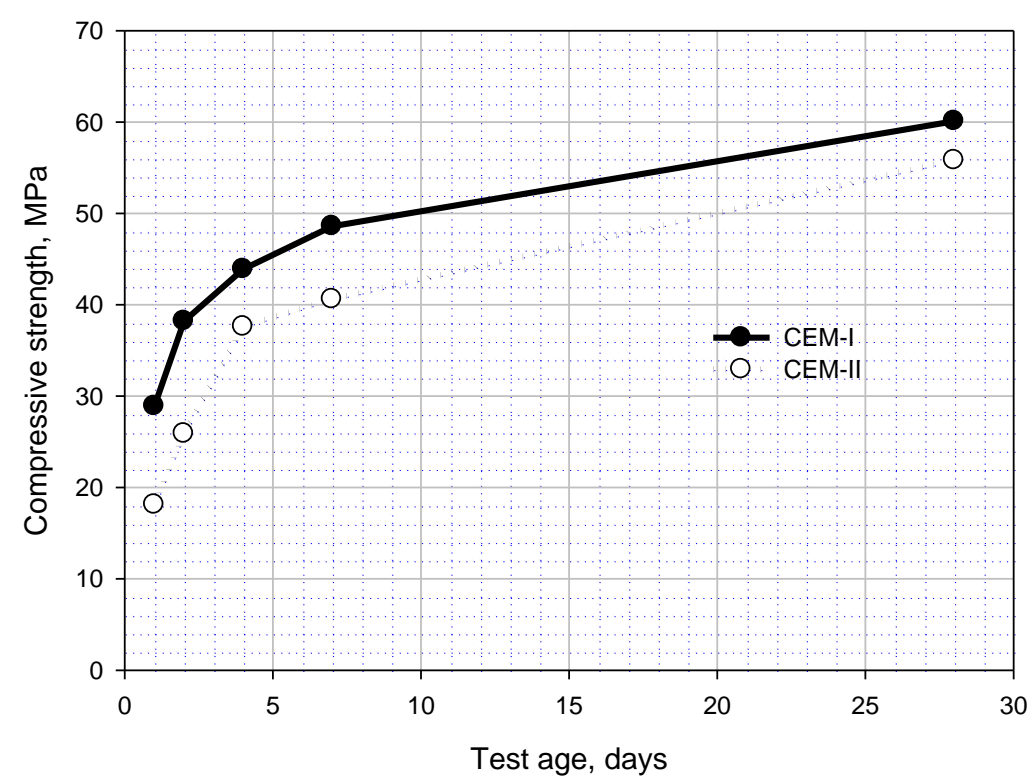

Figure 1. Compressive strength development of standard cured specimens

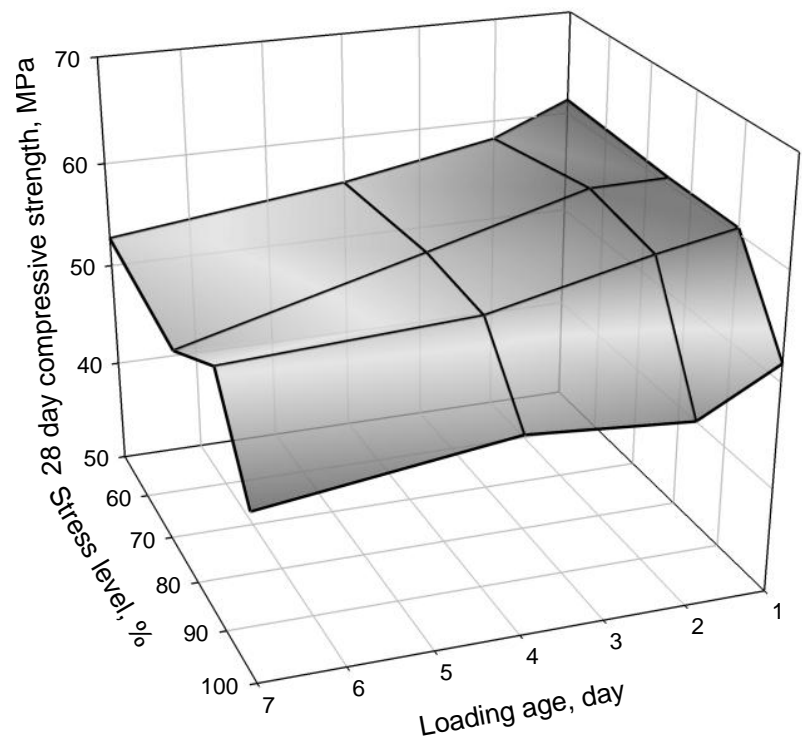

Figure 2. Compressive strength values of standard cured CEM I specimens after various stress application at different loading ages

Abdel-Jawad and Haddad reported the effect of early over-loading of concrete on its strength development [10]. Concrete and mortar samples were subjected to different loading levels at ages of $8,16,24$ and 72 hours. The samples were then retested, along with control specimens, at ages of 7,28 , and 90 days. The results indicate that loading concrete, beyond 8 hours after casting, up to $90 \%$ of its compressive strength has no effect on later strength development. However, loading concrete up to failure resulted in strength loss 
between $10 \%$ to $50 \%$, depending on age at time of loading, age at time of retesting and curing conditions.

Compressive strength value variations of steam cured CEM I specimens after various stress application at different loading ages were given in Figure 3.

Figure 3 shows the results that steam curing after preloading could not provide expected contribution. Ultimate strength values were in the range of 41-46 $\mathrm{MPa}$ for 50,75 and $90 \%$ preloading levels, independent from the preloading age. Fully damaged i.e. $100 \%$ preloaded specimens had 35-37 MPa compressive strength after steam curing application.

Steam curing application after preloading caused lower $28^{\text {th }}$ day compressive strength values but more stable results. Variation in preloading age or in preloading level did not greatly affect the strength gain after steam curing. This argument was in conformity with fact that steam curing causes porous, heterogenic microstructure in Portland cement systems. By an impressed thermal treatment a dense microstructure forms around the cement particles. On the contrary, capillary pores could not filled by hydration products. Thus a strength value less than the strength capacity of composite could be obtained.

Steam curing application after preloading thought to cause same manner even at relatively later ages.

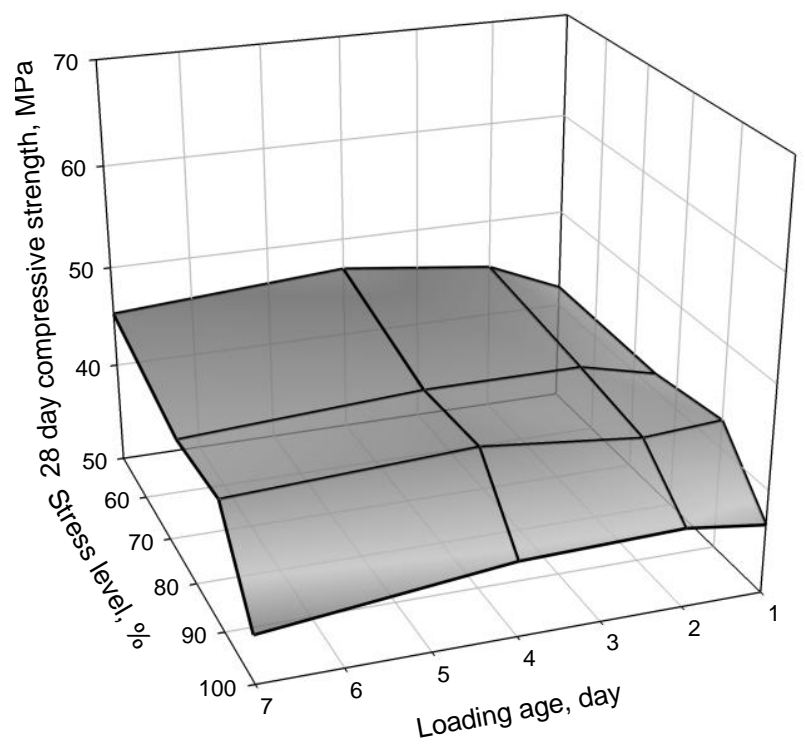

Figure 3. Compressive strength values of steam cured CEM I specimens after various stress application at different loading ages

Figure 4 shows the result of air cured specimens after preloading. In this series, specimens were water cured until first loading and preloaded up to target strength percent then kept in air until $28^{\text {th }}$ day. Thus curing process was very limited and hydration environment was altered after a short period of time especially for $1^{\text {st }}$ day of preloading age.

Interestingly strength gain of these series of specimens was considerably greater 
compared to steam cured series. Two mechanisms were thought to be activated the strength gain. First, the humidity inside the specimen maintained the hydration progress. Compared to steam curing process a more homogenous microstructure could be achieved. The second was drying process. It is well known that dry samples exhibits 10-15\% greater values in terms of measured strength.

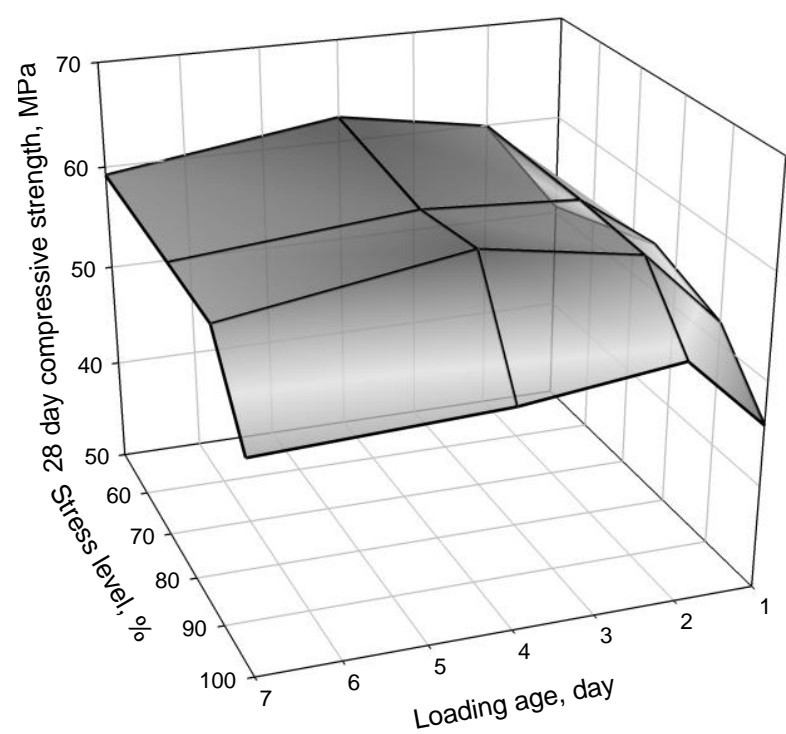

Figure 4. Compressive strength values of air cured CEM I specimens after various stress application at different loading ages

Compared to standard curing, air cured specimens which were preloaded relatively at later ages for example 4 and 7 days, gained greater strength values. The crack free areas were well cured, and after preloading crack surfaces may get closer by drying. Besides, ongoing hydration progress with inner humidity strengthened the crack zones of the composite. In this way, even fully damaged specimens at $7^{\text {th }}$ day indicated $50.3 \mathrm{MPa}$ of compressive strength at $28^{\text {th }}$ day.

Compressive strength value variations versus preloading age and stress level for standard cured CEM II specimens were given in Figure 5. Compared to CEM I specimens the only difference was the lower final strength values for the specimens those preloaded at $1^{\text {st }}$ and $2^{\text {nd }}$ day. Later age of preloading caused similar compressive strength values with CEM I specimens. In fact a greater strength gain was occurred especially for early ages. For example, in the case of preloading a compressive stress of 100 $\%$ of instantaneous strength at $1^{\text {st }}$ day, resulted in 29.3 MPa strength gain (17.4 $\mathrm{MPa}$ to $46.7 \mathrm{MPa}$ ) for CEM II, while the corresponding strength gain value was 22.2 $\mathrm{MPa}$ (29.5 $\mathrm{MPa}$ to $51.7 \mathrm{MPa}$ ) for CEM I. 


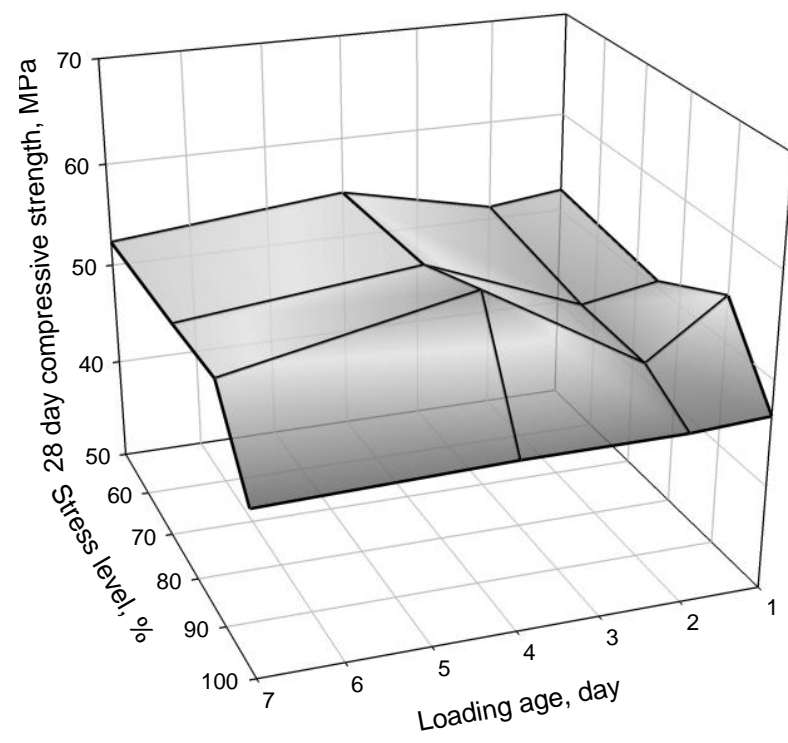

Figure 5. Compressive strength values of standard cured CEM II specimens after various stress application at different loading ages

Figure 6 depicts the compressive strength values of steam cured CEM II specimens after various stress application at different loading ages. Steam cured blended cement mortar specimens after preloading exhibited same behavior same as ordinary Portland cement mortar specimens. The only difference was somewhat greater compressive strength values after 28 days. This situation was an indicator that impressive thermal treatment provided more benefits for blended cement. It was supposed that, this contribution was provided by higher activation of pozzolanic fly ash at elevated temperatures during steam curing process.

Compressive strength values of air cured CEM II specimens after various preloading are represented in Figure 7.
A dramatic reduction in $28^{\text {th }}$ day compressive strength values have been observed in blended cement mortars at early age preloaded specimens compared to ordinary Portland cement mortar specimens. Insufficient curing of blended specimens resulted in a sharp strength loss even they were not fully damaged.

On the other hand, compressive strength values of the specimens preloaded without full damage at 7 days were above the $60 \mathrm{MPa}$.

In the case of $100 \%$ preloading, 42-48 $\mathrm{MPa}$ compressive strength values have been achieved with an increasing trend versus preloading age. 


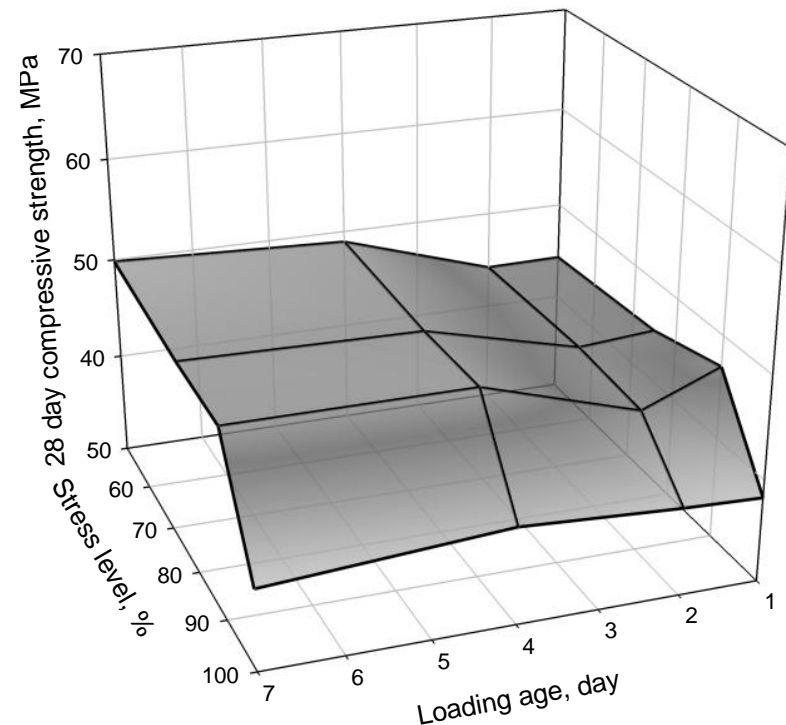

Figure 6. Compressive strength values of steam cured CEM II specimens after various stress application at different loading ages

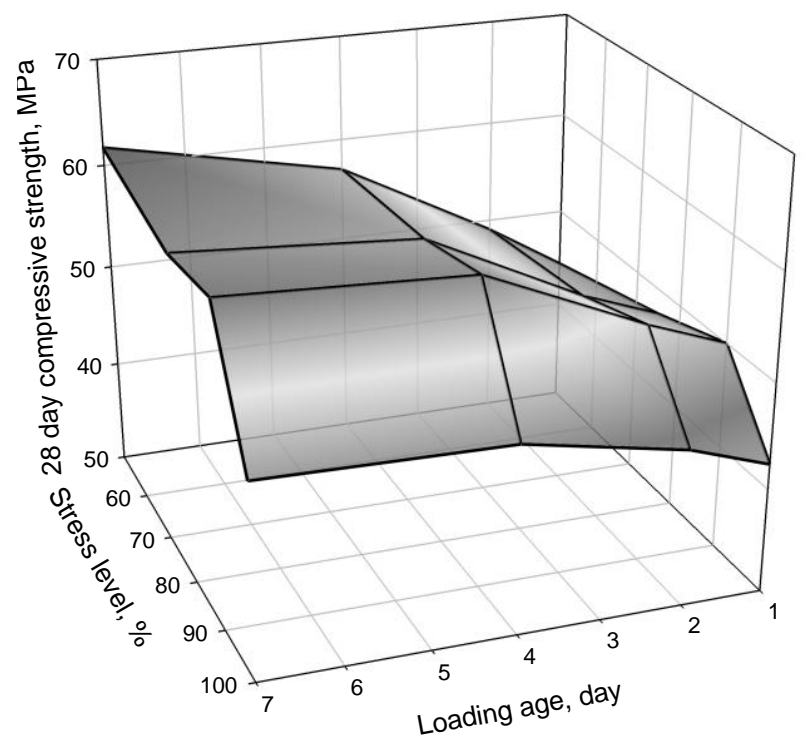

Figure 7. Compressive strength values of air cured CEM II specimens after various stress application at different loading ages

To perform a brief microstructural observation an optical digital microscope with 250x magnification was used. Micrograph of standard cured CEM-I specimen preloaded at $1^{\text {st }}$ day given in Figure 8-a. It can be seen that cracks were healed during the standard curing process. The image was taken from the surface of cubic specimen after $28^{\text {th }}$ day final test. Crack opening was occurred again after the final test. Healing product thickness was 
measured approximately $75 \mu \mathrm{m}$ in each side of the crack.

Aggregate-matrix transition zone of the same group of the specimen was shown in Figure 8-b which was taken before the $28^{\text {th }}$ day final test. Healing products almost fulfilled the crack around the sand particle. A small part of the crack still remains unfilled. Detailed discussion for the similar healed cracks could be found in the study by Hilloulin et al. [19].
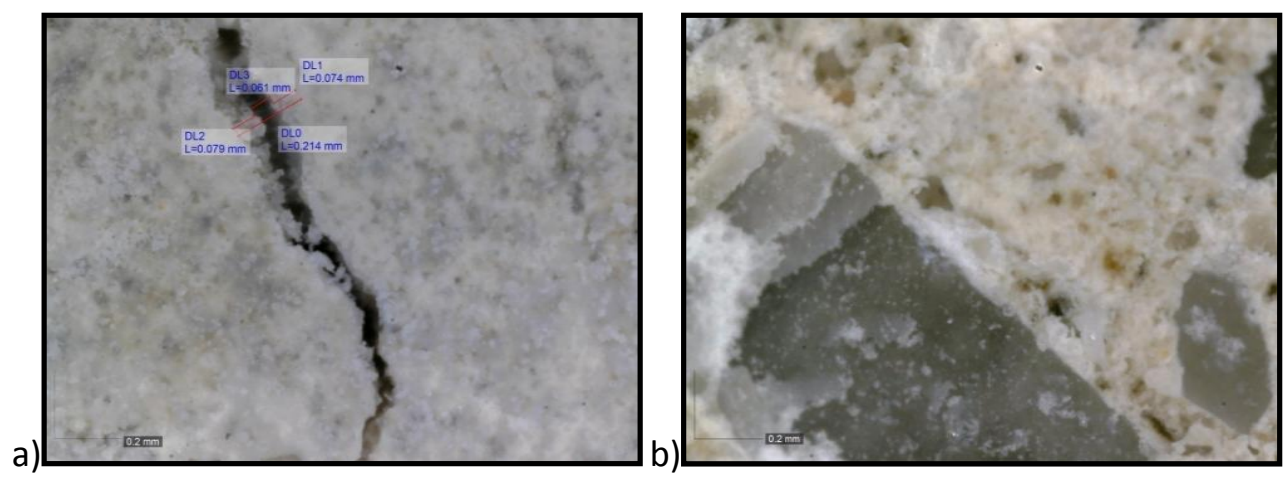

Figure 8. Micrographs of CEM-I specimens which were standard cured after preloading at 1st day up to $100 \%$ of compressive strength a) surface after 28th day final test b) interior before 28th day final test.

Micrographs of the steam cured specimens after preloading at $1^{\text {st }}$ day up to $100 \%$ of compressive strength are given in Figure 9-a for CEM-I and in Figure 9-b for CEM-II. It was revealed that $100{ }^{\circ} \mathrm{C}$ steam curing for $12 \mathrm{~h}$ could not repair the cracks.

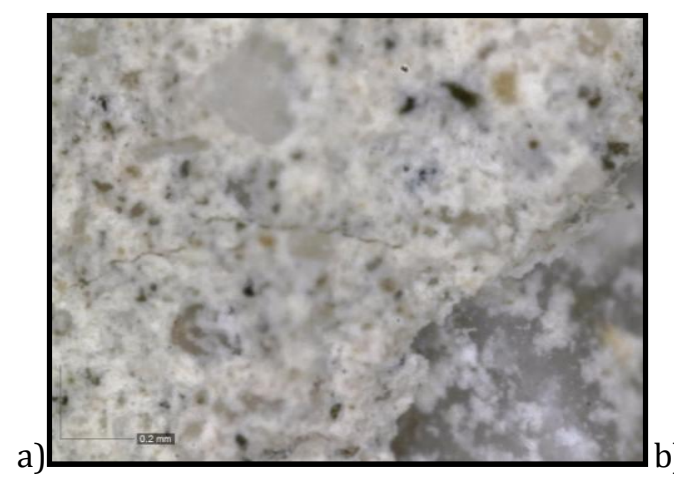

Micrographs of CEM-I specimens which were air cured after preloading at $1^{\text {st }}$ day up to $100 \%$ of compressive strength were given in Figure 10 -a for the surface and in Figure 10-b for interior before $28^{\text {th }}$ day final test. In a similar manner with steam curing process, air curing process could not heal the cracks.

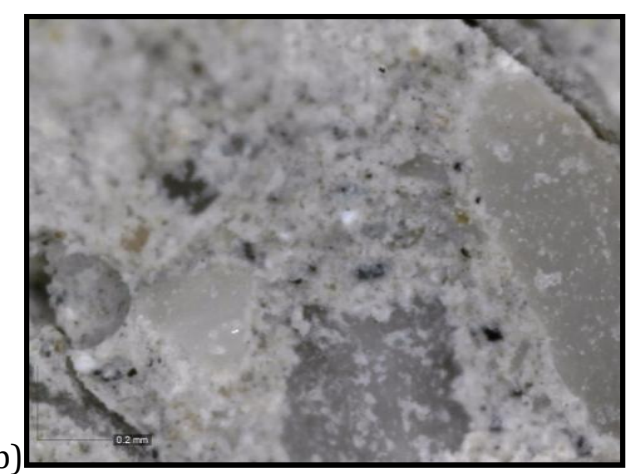

Figure 9. Images of steam cured specimens preloaded at $1^{\text {st }}$ day up to $100 \%$ of compressive strength a) CEM-I b) CEM-II. 

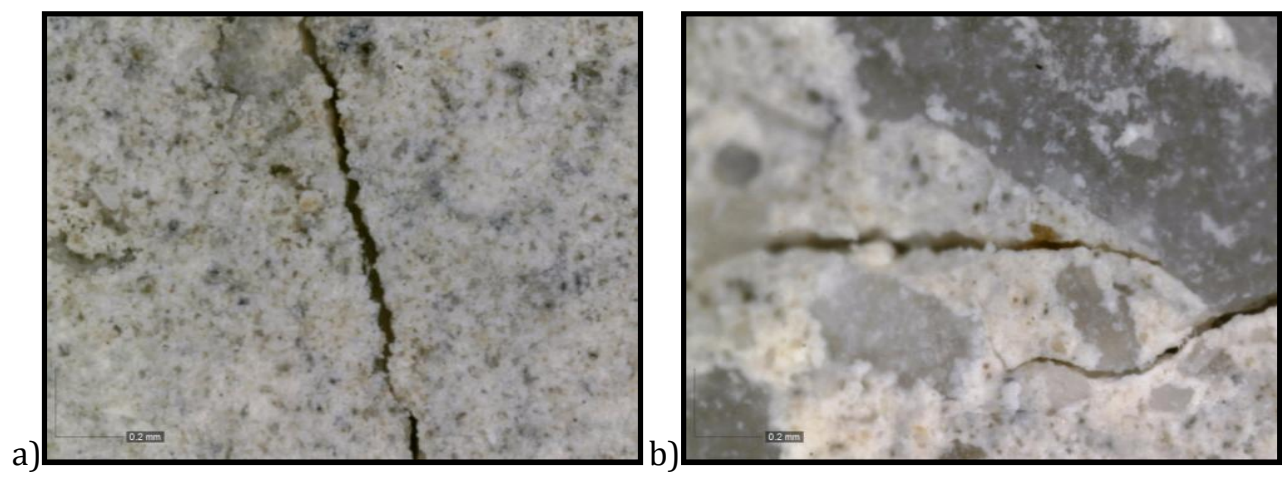

Figure 10. Micrographs of CEM-I specimens which were air cured after preloading at $1^{\text {st }}$ day up to $100 \%$ of compressive strength a) surface before $28^{\text {th }}$ day final test b) interior before $28^{\text {th }}$ day final test.

\section{Conclusions}

The following items can be drawn from the results of given experimental study.

Pre-stressing level has a great importance on ultimate strength. Also it seems that it has a threshold level between $90-100 \%$.

$>\quad$ Lowering the preloading level under $90 \%$ of instantaneous strength, do not affect the ultimate strength of standard cured specimens especially for the preloading at early ages.

$>\quad$ On the contrary, results obtained from air cured specimens preloaded at relatively later ages were almost equal or greater than that of control specimens.

Steam curing application after preloading caused lower 28th day compressive strength values but more stable results. Variation in preloading age or in preloading level did not greatly affect the strength gain after steam curing. It can be said that, steam curing after a damage had a limited efficiency but provide closer strength values with respect to preloading age or preloading stress level.
$>$ Blended cement mortar specimens achieved better results with steam curing process.

\section{Acknowledgement}

The author would like to thank to Mr.Ilkan Akıncıoğlu for his great assistance during experimental works.

\section{References}

[1] Jacobsen, S., Marchand, J., Boisvert, L. 1996. Effect of Cracking and Healing on Chloride Transport in OPC Concrete, Cement and Concrete Research, Vol. 26, p. 869-881.

[2] Hearn, N. 1998. Self-sealing, Autogenous Healing and Continued Hydration: What is the Difference?, Materials and Structures, Vol. 31, p. 563-567.

[3] Edvardsen, C. 1999. Water Permeability and Autogenous Healing of Cracks in Concrete, $A C I$ Materials Journal, Vol. 96, p. 448454.

[4] Aldea, C., Song, W., Popovics, J., Shah, S. 2000. Extent of Healing of Cracked Normal Strength Concrete, Journal of Materials in Civil Engineering, Vol. 12, p. 92-96. 
[5] Gerard, B., Marchand, J. 2000. Influence of Cracking on the Diffusion Properties of CementBased Materials - Part I: Influence of Continuous Cracks on the Steadystate Regime, Cement and Concrete Research, Vol. 30, p. 3743.

[6] Reinhardt, H.W., Jooss, M. 2003. Permeability and Self-Healing of Cracked Concrete as a Function of Temperature and Crack Width, Cement and Concrete Research, Vol. 33, p. 981-985.

[7] Granger, S., Loukili, A., PijaudierCabot, G., Chanvillard, G. 2007. Experimental Characterization of the Self-Healing of Cracks in an Ultra High Performance Cementitious Material: Mechanical Tests and Acoustic Emission Analysis, Cement and Concrete Research, Vol. 37, p. 519-527.

[8] Alyousif, A., Lachemi, M., Yıldırım, G., Şahmaran, M. 2015. Effect of Self-Healing on the Different Transport Properties of Cementitious Composites, Journal of Advanced Concrete Technology, Vol. 13, p. 112-123.

[9] Homma, D., Mihashi, H., Nishiwaki, T. 2009. Self-Healing Capability of Fibre Reinforced Cementitious Composites, Journal of Advanced Concrete Technology, Vol. 7, p. 217228.

[10] Abdel-Jawad, Y., Haddad, R. 1992. Effect of Early Overloading of Concrete on Strength at Later Ages, Cement and Concrete Research, Vol. 22, p. 927-936.

[11] Zhong, W., Yao, W. 2008. Influence of Damage Degree on Self-Healing of Concrete, Construction and Building Materials, Vol. 22, p. 1137-1142.
[12] Luo, M., Qian, C.X., Li, R.Y. 2015. Factors Affecting Crack Repairing Capacity of Bacteria-Based SelfHealing Concrete, Construction and Building Materials, Vol. 87, p. 1-7.

[13] Jonkers, H.M., Schlangen, E. 2008. Development of a Bacteria-Based Self Healing Concrete, Tailor Made Concrete Structures, London, p. 425-430.

[14] Jiang, Z., Li, W., Yuan, Z. 2015. Influence of Mineral Additives and Environmental Conditions on the Self-Healing Capabilities of Cementitious Materials, Cement and Concrete Composites, Vol. 57, p. 116-127.

[15] Hosoda, A., Kishi, T., Arita, H., Takakuwa, Y. 2007. Self Healing of Crack and Water Permeability of Expansive Concrete, 1st International Conference on Self Healing Materials, Noordwijk, p. 110.

[16] Ramezanianpour, A.M., Esmaeili, K., Ghahari, S.A., Ramezanianpour, A.A. 2014. Influence of Initial Steam Curing and Different Types of Mineral Additives on Mechanical and Durability Properties of SelfCompacting Concrete, Construction and Building Materials, Vol. 73, p. 187-194.

[17] Türkel, S., Alabaș, V. 2005. The Effect of Excessive Steam Curing on Portland Composite Cement Concrete, Cement and Concrete Research, Vol. 35, p. 405- 411.

[18] Ba, M.F., Qian, C.X., Guo, X.J., Han, X.Y. 2011. Effects of Steam Curing on Strength and Porous Structure of Concrete with Low Water/Binder Ratio, Construction and Building Materials, Vol. 25, p. 123-128.

[19] Hilloulin, B., Hilloulin, D., Grondin, F., Loukili, A., Belie, N. 2016. 
H. Yiğiter / Effectiveness of Steam Curing on Repairing Early Age Mortar Damages

Mechanical Regains Due to Self-

Healing in Cementitious Materials:

Experimental Measurements and

Micro-Mechanical Model, Cement

and Concrete Research, Vol. 80, p.

21-32. 